\title{
Pathogenicity of nodavirus strains from striped jack Pseudocaranx dentex and Atlantic halibut Hippoglossus hippoglossus, studied by waterborne challenge of yolk-sac larvae of both teleost species
}

\author{
Geir K. Totland ${ }^{1, *}$, Sindre Grotmol ${ }^{2}$, Yuseku Morita ${ }^{3}$, Toyohiro Nishioka ${ }^{4}$, \\ Toshihiro Nakai ${ }^{3}$ \\ ${ }^{1}$ Department of Zoology, University of Bergen, Allégt. 41, 5007 Bergen, Norway \\ ${ }^{2}$ Department of Aquaculture, Institute of Marine Research, PO Box 1870 Nordnes, 5024 Bergen, Norway \\ ${ }^{3}$ Fish Pathology Laboratory, Faculty of Applied Biological Science, Hiroshima University, Higashihiroshima 739, Japan \\ ${ }^{4}$ Goto Station of Japan Sea-Farming Association, Tamanoura, Nagasaki 0853-0501, Japan
}

\begin{abstract}
The present study shows that differences in pathogenicity exist among fish nodavirus strains. In challenge trials, a Japanese strain (SJ93Nag) was highly virulent to larvae of the striped jack Pseudocaranx dentex but replication was not detected in larvae of Atlantic halibut Hippoglossus hippoglossus at $6^{\circ} \mathrm{C}$. Conversely, a Norwegian nodavirus strain (AH95NorA) that was highly virulent to the Atlantic halibut larvae did not replicate in striped jack larvae at $20^{\circ} \mathrm{C}$. Occurrence of the disease viral encephalopathy and retinopathy (VER) and cumulative mortality were significantly different in the 2 species when challenged with the 2 nodavirus strains. The presence of nodavirus in nervous tissue was monitored by immunohistochemical methods. Our results support the view that the genetic diversity among nodavirus strains reflects the existence of different viral phenotypes which may be adapted to infect different host species and/or for replicating at different temperatures. Fish nodaviruses represent surveyable pathogens well suited for studying the relation between viral genotypic and phenotypic properties such as host specificity, temperature optima, neuroinvasiveness and neurovirulence.
\end{abstract}

KEY WORDS: Striped jack - Atlantic halibut - Fish nodavirus - Pathogenicity - Virulence - Host specificity Immunohistochemistry

\section{INTRODUCTION}

Fish nodavirus infections are a major problem for marine aquaculture in most parts of the world. These infections strike larvae and juveniles, in rare cases also adults, and have caused severe losses in more than 19 cultured teleost species (Munday \& Nakai 1997). Fish nodaviruses are neuropathogenic and for this reason the disease has variously been called viral nervous necrosis (VNN) (Yoshikoshi \& Inuoe 1990), fish ence-

•E-mail: geir.totland@zoo.uib.no phalitis (Breuil et al. 1991) or viral encephalopathy and retinopathy (VER) (Munday et al. 1992). The most conspicuous lesions are found in the central nervous system (CNS) and the retina and are characterised by cellular vacuolation and neuronal degeneration.

In order to obtain a better understanding of the epidemiology of the disease, information on the existence of phenotypic differences among fish nodavirus strains such as host specificity, temperature optima or virulence is essential. Information on the structure of the virion and the genetic variation among fish nodaviruses has been published (Mori et al. 1992, Comps et al. 1994, Nishizawa et al. 1995, 1997). Nodaviruses are 
unenveloped with icosahedral capsids with diameters in the range of 25 to $30 \mathrm{~nm}$. Their genomes consist of 2 segments of messenger sense RNA (RNA1 and RNA2), both encapsidated in the same virion (Mori et al. 1992, Comps et al. 1994). RNA1 encodes a non-structural protein, presumably a component of an RNA-dependent RNA polymerase. RNA2 has a single open reading frame that encodes the capsid protein. The complete sequence of the RNA2 of the striped jack nervous necrosis virus (SJNNV) has been determined, and an amino acid sequence similarity of $80.9 \%$ or higher was found between SJNNV and fragments (T2 region; approx. 870 bases) of 4 other Japanese nodaviruses (Nishizawa et al. 1995). A molecular phylogenetic analysis based on the sequence of 430 bases (T4 region) within the capsid protein gene of 25 nodavirus strains revealed a phylogenetic tree diverging into 4 major clusters, designated as striped jack type, tiger puffer type, barfin flounder type and red spotted grouper type, respectively (Nishizawa et al. 1997). The nuclotide sequence of the capsid protein gene of a nodavirus from the Atlantic halibut (AH95NorA) showed a close relationship to the barfin flounder type nodaviruses (Grotmol et al. in press), all of which are from cold-water teleosts (Pacific cod and barfin flounder). The variable regions of the capsid protein gene (T4) of the nodavirus from striped jack and Atlantic halibut are $66 \%$ identical in base sequences (Grotmol et al. in press), and these viruses, which were employed in this study, are thus among the most distantly related fish nodaviruses known.

High pathogenicity of the SJNNV to striped jack yolk-sac larvae at 18 to $27^{\circ} \mathrm{C}$ has been demonstrated experimentally (Arimoto et al. 1994). Likewise, the AH95NorA strain from the Atlantic halibut is highly virulent to yolk-sac larvae of the same species at $6^{\circ} \mathrm{C}$ (Grotmol et al. 1999). The aim of our study was to compare the virulence of 2 nodavirus strains from striped jack and Atlantic halibut, by infecting yolk-sac larvae of both teleost species with both virus strains.

\section{MATERIALS AND METHODS}

Eggs and larvae. Striped jack: Fertilised eggs of striped jack were produced by a spawning group at the Goto Station (Japan) of the Japan Sea-Farming Association (JASFA). Eggs and larvae were reared in $100 \mathrm{l}$ tanks at 20 to $22^{\circ} \mathrm{C}$ prior to the experiment. The presence of nodavirus in the gonadal fluids of the broodstock prior to spawning and in the newly hatched larvae was tested by reverse transcriptase polymerase chain reaction (RT-PCR) using the R3 and F2 primers (Nishizawa et al. 1994). No PCR products were generated.
Atlantic halibut: Two separate batches of eggs and sperm were obtained by stripping 2 females and 2 males of the wild-caught broodstock at Austevoll Aquaculture Research Station (Norway). The fertilisation rate was better than $95 \%$ in both batches. Until the experiments started, the eggs were reared in $250 \mathrm{l}$ upwelling incubators at 6 to $7^{\circ} \mathrm{C}$, as described by Pittman et al. (1990). From each egg batch 20 larvae were tested using RT-PCR and nodavirus was not detected.

Virus materials for challenge. Infectious materials: Striped jack larvae infected with SJNNV were collected at the Goto Station of JASFA during a disease outbreak in 1993 and stored at $-80^{\circ} \mathrm{C}$ until used. The same infectious material had been employed in a previous infection study (Nguyen et al. 1996) and the virus strain is identical to SJ93Nag (Nishizawa et al. 1997).

Atlantic halibut larvae and juveniles were collected during episodes of acute high mortality in a commercial hatchery. Histopathological and electronmicroscopical examinations revealed vacuolating encephalopathy and retinopathy associated with a nodaviruslike agent as described by Grotmol et al. (1997). The virus strain is denoted AH95NorA (Grotmol et al. in press).

Preparation of inoculi: Two infectious homogenates from striped jack and Atlantic halibut, respectively, were prepared according to the following procedure: $2 \mathrm{~g}$ of tissue, consisting of whole larvae (striped jack) and the eyes, crania and vertebral columns (Atlantic halibut), was homogenised in a $10 \mathrm{ml}$ Potter-Elvehjems tissue grinder with $10 \mathrm{ml}$ sterile $0.9 \% \mathrm{NaCl}(\mathrm{aq})$ or in $10 \mathrm{mM}$ PBS. The homogenate was cleared by centrifugation at $3000 \times g$ for $20 \mathrm{~min}$ at $4^{\circ} \mathrm{C}$, and the supernatant was filtered through a membrane with a pore size of $220 \mathrm{~nm}$. Control homogenates from Atlantic halibut juveniles that were not infected with nodavirus could not be obtained with certainty, so a control homogenate of healthy salmon fry was prepared according to the same protocol as was employed with the infectious material. In both infectious homogenates, nodavirus were detected by RT-PCR, while the homogenate for mock challenge was negative. Cultures of chinook salmon embryo cells (CHSE-214) were inoculated with the homogenates and no cytopathic effects were observed after 2 passages. The homogenates were applied undiluted in the challenge trials.

Rearing conditions. Striped jack: One-day-old larvae were used as experimental fish. Groups of 600 larvae were kept at $20^{\circ} \mathrm{C}$ in glass beakers containing $1 \mathrm{l}$ of sea

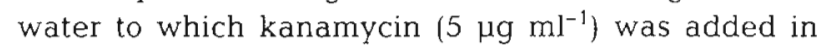
order to inhibit bacterial and fungal growth.

Atlantic halibut: The eggs and larvae were kept in complete darkness in a climate-regulated room at $6^{\circ} \mathrm{C}$. 
During periods of rearing and observation, the room was illuminated by a dim red light $(2.5 \mathrm{~lx})$. The eggs and larvae were incubated in 6 -well polystyrene tissue-culture plates (Multidish 6, Nunc, Roskilde, Denmark). The wells had a diameter of $35 \mathrm{~mm}$ and a depth of $18 \mathrm{~mm}$. Six days prior to hatching the wells were filled with $10 \mathrm{ml}$ autoclaved, diluted sea water (25\% salinity), and a single egg was transferred to each well (Bergh et al. 1992). Day 0 was defined as the day on which at least $50 \%$ of the eggs had hatched. On the following day (Day 1), $9 \mathrm{ml}$ of water and debris of the eggshell were removed from each well and replaced with fresh autoclaved diluted sea water (25\% salinity). The 6 -well plates were randomised and allocated to the experimental groups.

Infection trials. Challenge of striped jack larvae: Inoculation was performed by adding $0.5 \mathrm{ml}$ of the designated infectious homogenate to each beaker. Duplicated beakers were used for each virus challenge and the unchallenged control. During the $7 \mathrm{~d}$ observation period, 10 living larvae (including moribund) were sampled randomly each day for indirect fluorescent antibody technique (IFAT) and immunohistochemistry. The daily mortality was not recorded due to the rapid deterioration of the larvae after death.

Challenge of Atlantic halibut larvae: Two parallel infection trials were performed utilising larvae hatched from the 2 different egg batches, respectively. Each trial consisted of 4 groups. One group was challenged with undiluted infectious homogenate from Atlantic halibut $(\mathrm{AH}) ; 1$ group was challenged with undiluted homogenate from striped jack (SJ). For controls, 1 group was mock challenged with salmon fry homogenate (M) and 1 group was left unchallenged (C). The larvae were challenged by adding $100 \mu$ l of the designated homogenate to the water in each well. Each group consisted of 130 larvae. Sixty larvae were used to determine the cumulative mortality, while samples for immunohistochemistry were taken from the remaining 70 individuals. The mortality was recorded every second day until Day 52 and living larvae (including moribund) were sampled randomly from each group after the rise in the mortality rate. Larvae were defined as dead when they had lost their normal transparency and appeared grey, opaque and shrunken. Differences in mortality were checked for statistical significance by the chi-square contingency table test, assuming a binomial distribution of the data (Zar 1984).

Tissue preparation. Immunohistochemistry: Nodavirus antigens were detected using an avidin-biotinalkaline-phosphatase complex $(\mathrm{ABC} / \mathrm{AB})$ immunohistochemical technique modified from Hsu et al. (1981) and Evensen (1993). The primary antiserum was raised in rabbit against a recombinant partial capsid protein encoded by the RNA2 of SJNNV. Samples were fixed for $24 \mathrm{~h}$ in neutral phosphate-buffered $10 \%$ formalin, dehydrated through a graded ethanol series and embedded in paraffin. Sections, $3 \mu \mathrm{m}$ thick, were cut on a Reichert-Jung Biocut, deparaffinized at 58 to $59^{\circ} \mathrm{C}$ for 30 min, washed in 2 xylene baths, rehydrated through a series of decreasing concentrations of ethanol (100, $96,70,50 \%$ ) and brought to distilled water. Nonspecific antibody binding sites were blocked by covering the sections with a solution of $5 \%$ bovine serum albumin (BSA) in Tris-buffered saline (TBS, $\mathrm{pH} 7.4$ ) for $20 \mathrm{~min}$. The solution was blotted off the slides and the primary rabbit antiserum was incubated at a dilution of 1:900 in $2.5 \% \mathrm{BSA}$ in TBS for $30 \mathrm{~min}$. After washing for $5 \mathrm{~min}$ in TBS, the secondary antibody, biotinylated goat anti-rabbit immunoglobulin, diluted $1: 300$ in $2.5 \%$ BSA in TBS (Dakopatts, Glostrup, Denmark), was added and incubated for $30 \mathrm{~min}$. After washing in TBS, streptavidin alkaline phosphatase complex (diluted 1:1000; Boehringer, Darmstadt, Germany) was added and incubated at room temperature for $30 \mathrm{~min}$. After washing, New Fuchsin Chromogen (K698, Dako, California, USA) with $1 \mathrm{mM}$ levamisole (Sigma Co., London, UK) as inhibitor in TBS was added and allowed to develop for $5 \mathrm{~min}$. After washing in tap water, sections were counterstained with Mayer's haematoxylin and mounted in an aqueous mounting medium (Aquamount; BDH Laboratory Supplies, UK). All incubations were performed at room temperature in a humidity chamber. Tissue sections from all virus-challenged, mock-challenged and unchallenged groups were incubated with immune and non-immune serum (normal rabbit serum). The endpoint dilution of the primary antibody that gave an immunolabeling discernible from background was determined after 30 min of incubation at room temperature (Petrusz 1983).

IFAT: The paraffin sections were treated with $0.1 \%$ trypsin in $10 \mathrm{mM}$ PBS (pH 7.4) at $37^{\circ} \mathrm{C}$ for $30 \mathrm{~min}$ before incubation with an anti-SJNNV rabbit serum followed by FITC-conjugated swine Ig to rabbit Ig (Daco), as previously described by Nguyen et al. (1996). The IFAT was applied on sections of striped jack larvae.

Transmission electron microscopy: Whole larvae were submerged in fixative for at least $24 \mathrm{~h}$. A volume of $100 \mathrm{ml}$ fixative was made up of $10 \mathrm{ml} 10 \%$ formaldehyde (freshly prepared from paraformaldehyde), $10 \mathrm{ml}$ $25 \%$ glutaraldehyde, $20 \mathrm{ml} 0.2 \mathrm{M}$ cacodylate buffer and $60 \mathrm{ml}$ PBS ( $\mathrm{pH} 7.35$ ). After this primary fixation, the specimens were rinsed in buffer and postfixed in $1 \% \mathrm{OsO}_{4}$, dehydrated in ethanol and embedded in Epon 812 (Fluka Chemie AG, Switzerland). Ultrathin sections were contrasted in uranyl acetate and lead citrate and observed in a JEOL CX 100 transmission electron microscope. 


\section{RESULTS}

\section{Clinical signs and mortality}

\section{Striped jack}

The larvae exposed to SJ93Nag exhibited abnormal swimming with rotational movements and were occasionally observed lying still on the bottom. Approximately $30 \%$ of the larvae had died within $3 \mathrm{~d}$ after challenge with SJ93Nag and the cumulative mortality reached $100 \%$ on Day 4 . The groups inoculated with AH95NorA and the unchallenged controls did not show signs of disease and more than $90 \%$ of the larvae were still living on Day 7.

\section{Atlantic halibut}

The initial clinical sign was that larvae ceased swimming and were usually found lying on their sides with an abnormal ventral convexity (lordosis) of the vertebral column. Dark granules appeared in the dorsal portion of the yolk-sac and the size of these granules increased towards the terminal stages.
The cumulative mortality curves for the different groups are shown in Fig. 1. The cumulative mortality in the groups exposed to infectious Atlantic halibut homogenate ( $\mathrm{AH}-1$ and $\mathrm{AH}-2$ ), rose to $100 \%$ following a steep, sigmoid curve during the fourth week after challenge and the cumulative mortality was significantly higher from Day 24 onwards $(\mathrm{p}<0.001)$. The time from inoculation to $50 \%$ cumulative mortality $\left(\mathrm{LT}_{50}\right)$ for both the groups was $24 \mathrm{~d}$, reaching $100 \%$ mortality 2 d later.

The cumulative mortality curves of the groups inoculated with SJ93Nag (SJ-1 and SJ-2) followed a similar course as the mock-challenged groups, but with slightly lower cumulative mortality (Fig. 1). The $\mathrm{LT}_{50}$ of the mock- and SJ93Nag-challenged groups varied from 27 to $30 \mathrm{~d}$ and the cumulative mortality was significantly higher than in the unchallenged control groups from Day $26(p<0.001)$.

In the unchallenged groups the maximum cumulative mortality reached 45 and $47 \%$ after $50 \mathrm{~d}$ of trial. The maximum cumulative mortality of the mock- and SJ93Nag-challenged groups varied from 64 to $85 \%$ on Day 50 , when the experiment was terminated.

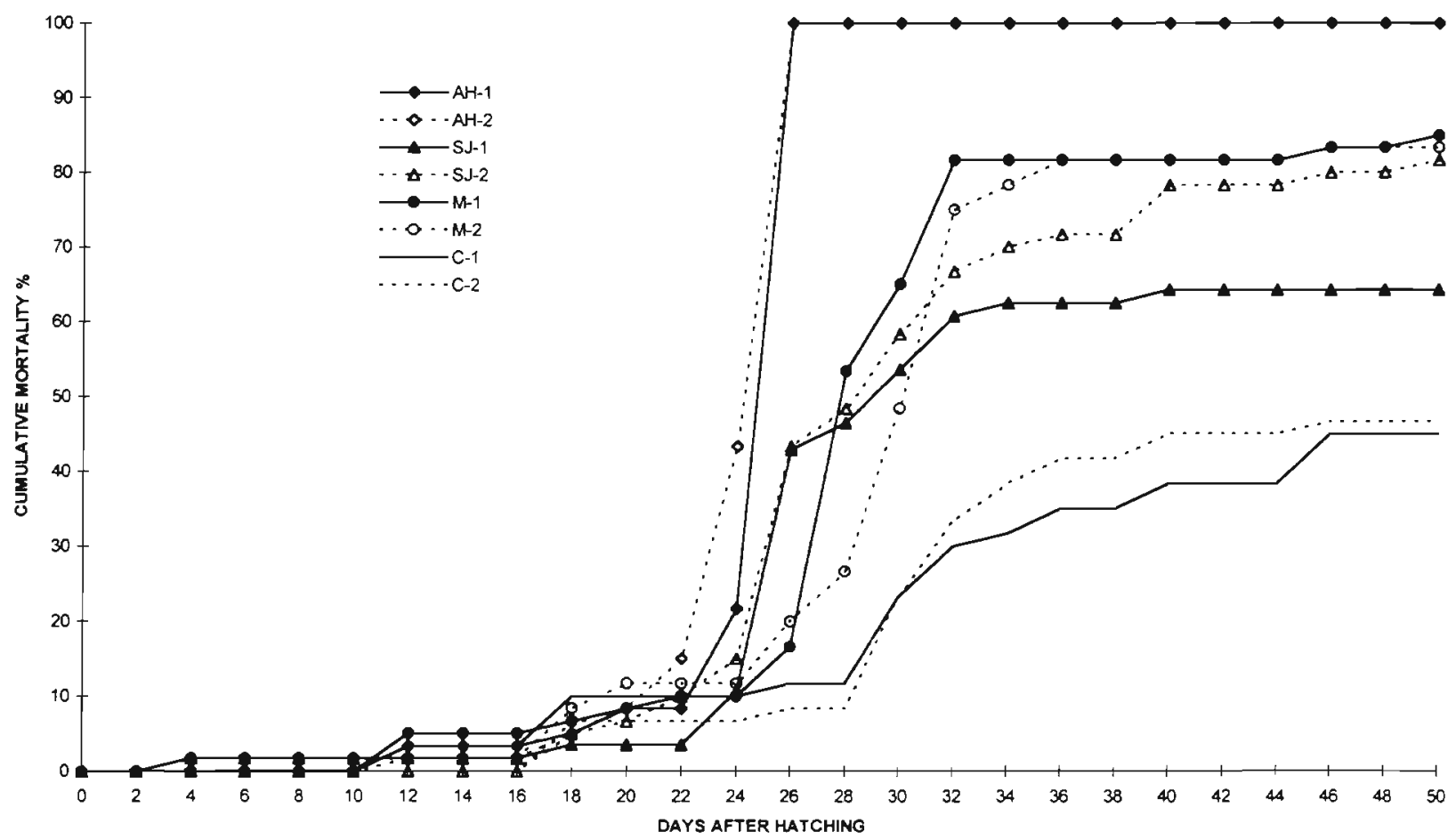

Fig. 1. Cumulative mortality curves of the experimental groups of the challenge trial on Atlantic halibut Hippoglossus hippoglossus yolk-sac larvae. The groups AH-1 and AH-2 were challenged with the nodavirus strain AH95NorA from Atlantic halibut. The groups SJ-1 and SJ-2 were challenged with SJ93Nag from striped jack, while M-1 and M-2 were mock-challenged with salmon fry homogenate and $\mathrm{C}-1$ and $\mathrm{C}-2$ were left unchallenged. In the 2 groups exposed to $\mathrm{AH} 95 \mathrm{Nor} A(\mathrm{AH}-1$ and $\mathrm{AH}-2$ ), the cumulative mortality rose from about 10 to $100 \%$ in the course of $2 \mathrm{~d}$ during the fourth week after challenge. The cumulative mortality curves of the 2 groups (SJ-1 and SJ-2) challenged with SJ93Nag and of the 2 mock challenged groups (M-1 and M-2) followed a similar course, and the cumulative mortality of these 4 ranged from 62 to $82 \%$ at termination. The cumulative mortality was significantly lower in the unchallenged control groups $(\mathrm{C}-1$ and $\mathrm{C}-2)$ from Day $26(\mathrm{p}<0.001)$ 


\section{Detection of virus and lesions}

\section{Striped jack}

Necrosis with vacuolation was observed in the CNS and retina only of the larvae challenged with SJ93Nag (Fig. 2). Some of the larvae sampled on Days 1 and 2 post-challenge showed characteristic lesions, but the strongest immunolabelling was observed $3 \mathrm{~d}$ postchallenge when all 10 larvae examined showed diffuse lesions (Figs. $2 \& 3$ ). The lesions and immunolabelling had identical characteristics to those observed during disease outbreaks and in previous studies (Nguyen et al. 1996). Neither lesions nor immunolabelling were observed in the nervous tissues of the AH95NorAchallenged (Fig. 4) and unchallenged groups.
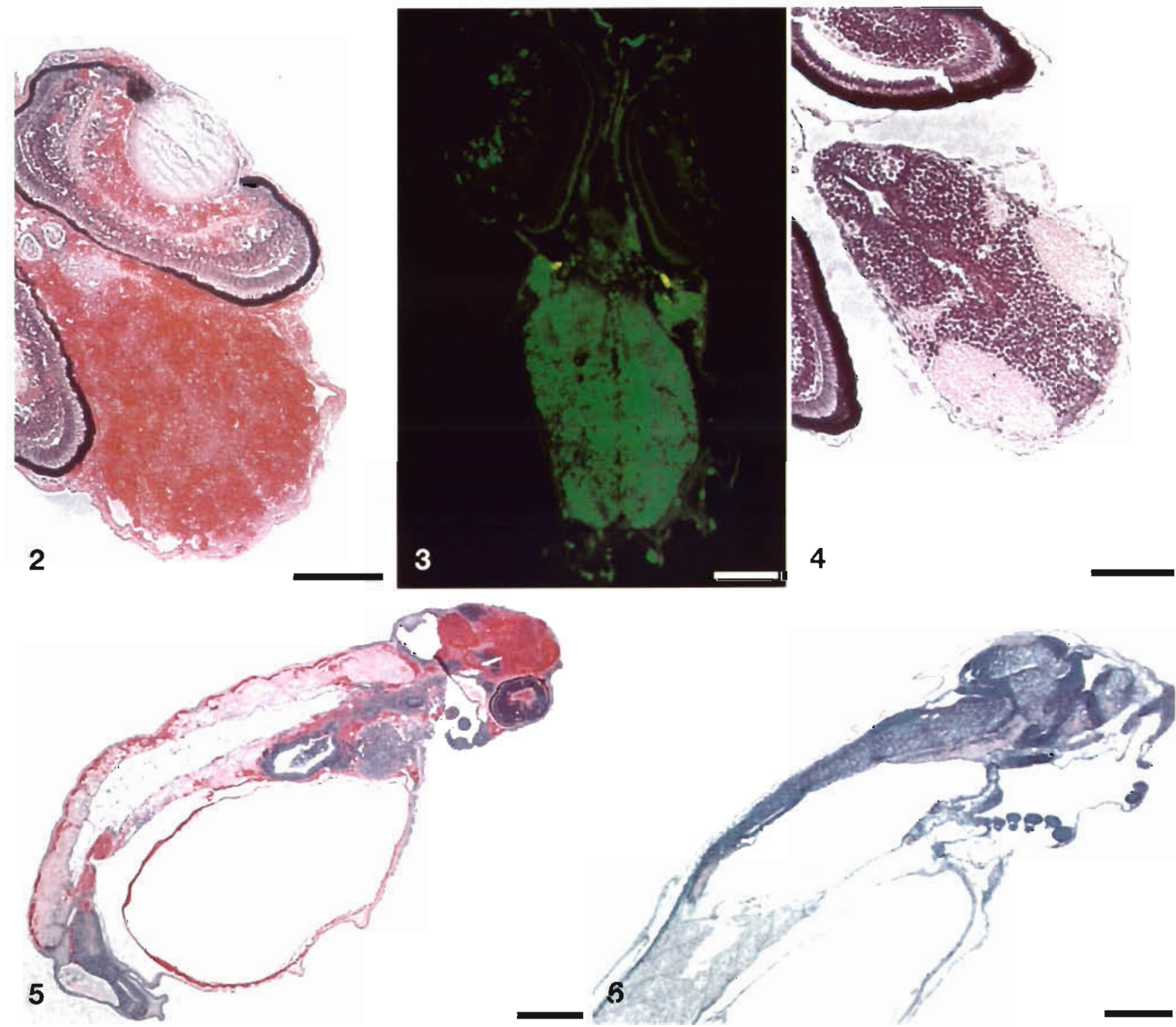

Figs. 2 to 6. Pseudocaranx dentex and Hippoglossus hippoglossus. Immunohistochemical staining of paraffin sections. Fig. 2. $P$. dentex. Brain and eyes. Larva 3 d after challenge with SJ93Nag. Note the diffuse immunolabelling. Avidin biotin alkaline phosphatase method, anti-SJNNV serum and Mayer's haematoxylin counterstain. Scale bar $=50 \mu \mathrm{m}$. Fig. 3. P. dentex. Brain and eyes. Larvae $3 \mathrm{~d}$ after challenge with SJ93Nag. Indirect fluorescent antibody technique (IFAT), anti-SJNNV serum. Scale bar $=50 \mu \mathrm{m}$. Fig. 4. P. dentex. Brain and eyes. Larvae $3 \mathrm{~d}$ after challenge with AH95NorA. Note the absence of immunolabelling. Scale bar $=$ $\overline{50 ~ \mu \mathrm{m}}$. Fig. 5. H. hippoglossus. Larva $23 \mathrm{~d}$ after challenge with AH95NorA. Note the diffuse immunolabelling. Avidin biotin alkaline phosphatase method, anti-SJNNV serum and Mayer's haematoxylin counterstain. Scale bar $=100 \mu \mathrm{m}$. Fig. 6 . H. hippoglossus. Larva $25 \mathrm{~d}$ after challenge with SJ93Nag. Note the absence of immunolabelling. Avidin biotin alkaline phosphatase method, anti-SJNNV serum and Mayer's haematoxylin counterstain. Scale bar $=100 \mu \mathrm{m}$ 


\section{Atlantic halibut}

While large amounts of nodavirus antigens were found in the Atlantic halibut larvae infected with AH95NorA (Fig. 5), no immunolabelling was detected in the SJ93Nag- (Fig. 6), mock-or unchallenged groups. In the larvae challenged with AH95NorA, specific immunolabelling was detected in the CNS, retina, intestinal anlage, liver anlage, yolk-sac epithelium, epidermis, myotomes and connective tissue (Fig. 5). Lesions were typical of VER and consisted of cellular vacuolation and degeneration.

\section{Electron microscopy}

Aggregations of spherical unenveloped virus particles with diameters of approximately $25 \mathrm{~nm}$ were observed in the lesions of fish from the same groups where immunolabelling was observed. The morphology of the virions was identical to those observed in the infectious material.

\section{DISCUSSION}

Reports on natural nodavirus infections (see review by Munday \& Nakai 1997) and challenge studies in various teleosts (Glazebrook et al. 1990, Mori et al. 1991, Arimoto et al. 1993, Nguyen et al. 1994, Danayadol et al. 1995, Boonyarathpalin et al. 1996, Grotmol et al. 1997, Le Breton et al. 1997, Thiery et al. 1997, Tanaka et al. 1998) all describe a disease with closely similar symptoms, pathology and epidemiology, but no challenge studies comparing nodavirus strains have been performed. In the present study, however, significant differences in viral pathogenicity were observed between 2 nodavirus strains when their natural host species were cross-infected. The underlying factors responsible for the observed differences in pathogenicity are unclear. Our results, however, support the view that genetic diversity among nodavirus strains (Nishizawa el al. 1997) reflects significant phenotypic differences which may constitute adaptations to enable infection of different hosts and/or replication at different temperature optima. It is not possible to conclude on the basis of our results whether the observed differences in pathogenicity between the 2 strains are an effect of water temperature or a result of host specificity. Further studies are needed to answer these questions.

Nodaviruses infect a number of marine teleosts, and the epidemiology of the disease indicates either that there is a low viral host specificity or that a diversity of host specific virus strains exists. Genetic differences among fish nodavirus strains have been demonstrated (Nishizawa et al. 1995, 1997, Sideris et al. 1997, Grotmol et al. in press). These studies are based on sequences of the gene encoding the capsid protein and may thus not reflect the total genetic heterogeneity of nodaviruses. A variable region (T4) of the capsid protein gene of SJ93Nag and AH95NorA is $66 \%$ identical in nucleotide sequence (Grotmol et al. in press), and these viruses, based on this criterion, are thus among the most distantly related fish nodaviruses known. The 2 teleosts used for challenge in this study belong to different taxonomic orders, and genetic differences may therefore be significant. Furthermore, genomic classification of fish nodaviruses (Nishizawa et al. 1997) revealed that closely related virus strains within the same clad having nearly identical capsid proteins may cause disease in a wide range of host species. Although the possibility cannot be ruled out that the differences in capsid protein structure may represent viral adaptation to different hosts, such an explanation seems less probable.

Natural infections of nodaviruses in marine fish occur within a wide range of water temperatures. The 2 teleost species used in our study were adapted to different water temperatures and the challenge studies were thus performed at 6 and $20^{\circ} \mathrm{C}$, respectively. The observed lack of virulence after cross-infection of the 2 fish species may be related to differences in water temperature. In experimental challenge studies with nodavirus on sevenband grouper and redspotted grouper, Tanaka et al. (1998) found a positive correlation between increasing water temperature and virulence. Another study (Arimoto et al. 1994) has also indicated that the nodavirus virulence increases as rearing temperature rises. Genomic classification of fish nodavirus strains (Nishizawa et al, 1997, Grotmol et al. in press) has demonstrated that the viruses affecting cold-water species are closely related, all belonging to the barfin flounder clad (Nishizawa et al. 1997). Genetic variation reflecting adaptations to water temperature may be related to the sequence of the RNA1, which is presumed to encode an RNA-dependent RNA polymerase.

Current knowledge of the nodavirus genome does not permit identification of genetic components relating to specific viral phenotypical features such as host range, virulence and temperature optima. Fish nodaviruses, however, represent surveyable pathogens well suited for studying these relations. Their genomes are among the smallest known (approx. $4.5 \mathrm{~kb}$ ), making it possible to determine functions of specific gene sequences. Further genetic studies, including complete genome sequences of multiple strains, are thus needed to unravel the complete genetic heterogeneity and its relation to viral phenotypic diversity. 
Acknowledgements. The authors thank research director Brit K. Hjeltnes, Institute of Marine Research, Norway, for providing excellent working facilities. Ingrid Uglenes, Tove Boge Eriksen and Teresa Cieplinska are thanked for excellent technical assistance. The study was partly financed by the Research Council of Norway.

\section{LITERATURE CITED}

Arimoto M, Mori K, Nakai T, Muroga K, Furusawa I (1993) Pathogenicity of the causative agent of viral nervous necrosis disease in striped jack, Pseudocaranx dentex. J Fish Dis 16:461-469

Arimoto M, Maruyama K, Furusawa I (1994) Epizootiology of viral nervous necrosis (VNN) in striped jack. Fish Pathol 29:19-24

Bergh $\varnothing$, Hansen GH, Taxt RE (1992) Experimental infection of eggs and yolk-sac larvae of halibut, Hippoglossus hippoglossus L. J Fish Dis 15:379-391

Boonyarathpalin S, Supamattaya K, Kasornchandra J, Hoffmann RW (1996) Picorna-like virus associated with mortality and spongious encephalopathy in grouper Epinephelus malabaricus. Dis Aquat Org 26:75-80

Breuil G, Bonami JR, Pichot Y (1991) Viral infection (picornalike virus) associated with mass mortalities in hatcheryreared sea-bass (Dicentrarchus labrax) larvae and juveniles. Aquaculture 97:109-116

Comps M, Pepin JF, Bonami JR (1994) Purification and characterization of two fish encephalitis virus (FEV) infecting Lates calcarifer and Dicentrarchus labrax. Aquaculture 123:1-10

Danayadol Y, Direkbusarakom S, Supamattaya K (1995) Viral nervous necrosis in brownspotted grouper, Einephelus malabaricus, cultured in Thailand. In: Shariff, M, Arthus JR, Subasinghe RP (eds) Diseases in Asian aquaculture II. Fish Health Section, Asian Fisheries Society, Manila, p 227-233

Evensen (1993) An immunohistochemical study on the cytogenetic origin of pulmonary multinucleate giant cells in porcine dermatosis vegitans. Vet Pathol 31:162-170

Glazebrook JS, Heasman MP, de Beer SW (1990) Picorna-like viral particles associated with mass mortalities in larval barramundi, Lates calcarifer Bloch. J Fish Dis 13:245-249

Grotmol S, Totland GK, Thorud K, Hjeltnes BK (1997) Vacuolating encephalopathy and retinopathy associated with a nodavirus-like agent: a probable cause of mass mortality of cultured larval and juvenile Atlantic halibut Hippoglossus hippoglossus. Dis Aquat Org 29:85-97

Grotmol S, Bergh $\varnothing$, Totland GK (1999) Transmission of viral encephalopathy and retinopathy (VER) to yolk-sac larvae of the Atlantic halibut Hippoglossus hippoglossus: occurrence of nodavirus in various organs and a possible route of infection. Dis Aquat Org 36:95-106

Grotmol S, Nerland AH, Biering E, Totland GK, Nishizawa T (1999) Characterisation of the capsid protein gene from a nodavirus strain affecting the Atlantic halibut Hippoglossus hippoglossus and design of an optimal reversetranscriptase polymerase chain reaction (RT-PCR) detection assay. Dis Aquat Org (in press)

Hsu SM, Raine L, Fanger H (1981) Use of an avidin-biotinperoxidase complex $(A B C)$ in immunoperoxidase techniques: a comparison between $\mathrm{ABC}$ and unlabelled anti-

Editorial responsibility: Jo-Ann Leong,

Corvallis, Oregon, USA body (PAP) procedures. J Histochem Cytochem 29: $577-580$

Le Breton A, Grisez L, Sweetman J, Ollevier F (1997) Viral nervous necrosis (VNN) associated with mass mortalities in cage-reared sea bass, Dicentrarchus labrax (L.). J Fish Dis 20:145-151

Mori K, Nakai T, Nagahara M, Muroga K, Mekuchi T, Kanno $T$ (1991) A viral disease in hatchery-reared larvae and juveniles of redspotted grouper. Fish Pathol 26:209-210

Mori K, Nakai T, Muroga K, Arimoto M, Mushiake K, Furusawa I (1992) Properties of a new virus belonging to Nodaviridae found in larval striped jack (Pseudocaranx dentex) with nervous necrosis. Virology 187:368-371

Munday BL, Nakai T (1997) Special topic review: nodaviruses as pathogens in larval and juvenile marine finfish. World $\mathrm{J}$ Microbiol Biotechnol 13:375-381

Munday BL, Langdon JS, Hyatt A, Humphrey JD (1992) Mass mortality associated with a viral-induced vacuolating encephalopathy and retinopathy of larval and juvenile barramundi, Lates calcarifer Bloch. Aquaculture 103:197-211

Nguyen HD, Mekuchi T, Imura K, Nakai T, Nishizawa T, Muroga K (1994) Occurrence of viral nervous necrosis (VNN) in hatchery-reared juvenile Japanese flounder Paralichthys olivaceus. Fish Sci 60:551-554

Nguyen HD, Nakai T, Muroga K (1996) Progression of striped jack nervous necrosis virus (SJNNV) infection in naturally and experimentally infected striped jack Pseudocaranx dentex larvae. Dis Aquat Org 24:99-105

Nishizawa T, Mori K, Nakai T, Furusawa I, Muroga K (1994) Polymerase chain reaction (PCR) amplification of RNA of striped jack nervous necrosis virus (SJNNV). Dis Aquat Org 18:103-107

Nishizawa T, Mori K, Furuhashi M, Nakai T, Furusawa I, Muroga K (1995) Comparison of the coat protein genes of five fish nodaviruses, the causative agents of viral nervous necrosis in marine fish. J Gen Virol 76:1563-1569

Nishizawa T, Furuhashi M, Nagai T, Nakai T, Muroga K (1997) Genomic classification of fish nodaviruses by phylogenetic analysis of the coat protein gene. Appl Environ Microbiol 63(4):1633-1636

Petrusz P (1983) Essential requirements for the validity of immunocytochemical staining procedures. J Histochem Cytochem 31:177-179

Pittman K, Skiftesvik AB, Berg L (1990) Morphological and behavioural development of halibut Hippoglossus hippoglossus L. larvae. J Fish Biol 37:455-472

Sideris DC (1997) Cloning, expression and purification of the coat protein of encephalitis virus (DIEV) infecting Dicentrarchus labrax. Biochem Mol Biol Int 42:409-417

Tanaka S, Aoki H, Nakai T (1998) Pathogenicity of the nodavirus detected from diseased sevenband grouper Epinephelus septemfasciatus. Fish Pathol 33(1):31-36

Thiery R, Peducasse S, Castric J, Le Ven A, Jeffroy J, Baudin Laurencin F (1997) Experimental transmission of viral encephalopathy and retinopathy to juvenile sea bass ( $D i$ centrarchus labrax). Bull Eur Assoc Fish Pathol 17(3/4): $118-122$

Yoshikoshi K, Inuoe K (1990) Viral nervous necrosis in hatchery-reared larvae and juveniles of Japanese parrot-fish, Oplegnathus fasciatus (Temminck \& Schlegel). J Fish Dis 13:69-77

Zar JH (1984) Biostatistical analysis, 2nd edn. Prentice-Hall Inc, Engelwood Cliffs, NJ

Submitted: March 12, 1999; Accepted: September 8, 1999

Proofs received from author(s): November 11, 1999 